\title{
Ownership Structure And Market Valuation: The Case Of Very Small, Young, And Fast-Growing Firms \\ William Barnes ${ }^{1}$, (Email: barnesw@up.edu), University of Portland T. Harikumar ${ }^{2}$, (Email: sankaran@nmsu.edu), New Mexico State University Greg Roth ${ }^{3}$, (Email: gregroth@nmsu.edu), New Mexico State University
}

\begin{abstract}
In studies of primarily large, established firms, researchers find that increasing managerial ownership increases firm value, at least in some ranges of ownership. This evidence suggests that increasing managerial ownership can decrease net agency costs. Our study investigates managerial ownership and firm value for an atypical sample: very small, young, and fast-growing firms. We argue that increasing managerial ownership likely increases net agency costs in small, entrepreneurial firms. Consistent with this argument, we find that entrepreneurial firm value is positively related to outside board member ownership, but negatively related to inside board member ownership.
\end{abstract}

\section{INTRODUCTION}

he finance literature is rich with theories that explain the influence of ownership structure on firm value. Earlier writers argue that, from an outside shareholder's point of view, there are potential benefits and potential costs to increasing the share ownership of corporate management. Increasing managerial ownership can align the incentives of managers and outside shareholders by making managerial wealth more sensitive to changes in stock price. Thus, increasing managerial ownership can focus managers on share value maximization (Jensen and Meckling, 1976). Alternatively, increasing managerial ownership can entrench managers (Stulz, 1988) or lead them to choose risk-reducing projects that are not value maximizing (Amihud and Lev, 1981).

Prior researchers find that managerial ownership is positively related to firm value, at least over certain ranges of ownership. For example, in a study of Fortune 500 firms, Morck, Shleifer, and Vishny (1988) find that Tobin's $Q$ rises as inside ownership increases from 0 to $5 \%$, falls as inside board ownership increases from 5 to $25 \%$, and rises again as inside ownership climbs above $25 \%$. They observe the same curvilinear relationship between $Q$ and outside ownership. Morck, Shleifer, and Vishny (1988) specifically state in the conclusion of their article that they have focused on very large and older firms. They suggest that future research is needed to examine ownership structure in different types of firms.

McConnell and Servaes (1990) find that $Q$ increases with director and officer ownership until ownership reaches 40 to 50\%, but they do not distinguish between inside and outside directors. Mehran (1995) finds a positive, linear relationship, between CEO ownership and $Q$. Although McConnell and Servaes (1990) and Mehran (1995) include some small firms in their samples, their studies still emphasize larger, more established firms, relative to the typical U.S. business. For reasons explained below, the evidence from these studies cannot necessarily be generalized to "entrepreneurial firms," which we define as very small, young, and fast-growing firms.

We develop a unique sample of entrepreneurial firms with which to analyze the relationship between ownership structure and firm value. Entrepreneurial firms differ from other firms in important respects. First, because 
these firms are very small, they're more likely to become takeover targets. Comment and Schwert (1993) review the literature on takeover probability and they estimate factors that influence takeover probability. Comment and Schwert conclude that the only factor consistently shown to have an influence is firm size. Smaller firms are much more likely to become takeover targets than larger firms. Thus, managers of entrepreneurial firms should face relatively intense external monitoring and discipline from the corporate control market.

Second, because entrepreneurial firms are very small and young, they're more likely to have a high percentage of shares concentrated in the hands of outside directors (who are often professional financiers of young, high growth firms, e.g., venture capitalists). Obviously, the wealth constraints to ownership concentration are reduced for very small firms. In the event inside board members of entrepreneurial firms are not entrenched through their own high share ownership, outside board members with high share ownership can provide further external monitoring of managers, as well as valuable strategic advice. Finally, because entrepreneurial firms are fast growing, they're more likely to have valuable investment opportunities and less likely to suffer the agency costs of free cash flow.

These two characteristics of entrepreneurial firms, greater external monitoring of managers and lesser free cash flow, suggest that the benefits of increasing managerial ownership should be relatively low for entrepreneurial firm shareholders. If managers are closely monitored by outsiders and they have no free cash flow to squander, they are less able to take actions that harm outside shareholders. Thus, in a low range of managerial ownership, entrepreneurial firm managers should be more likely than other managers to act in shareholders' interests.

However, as the percentage of shares held by entrepreneurial firm managers increases, certain agency costs are likely to rise. As managerial ownership increases, managers bear more firm-specific risk and may become too conservative in managing the firm. This is costly to outside shareholders who hold relatively more diversified portfolios. Managers also become more entrenched as their share ownership increases. Of course these problems can occur in larger, established firms too. But earlier researchers have provided evidence that, at least in a low range of ownership, increasing managerial ownership provides a net benefit to outside shareholders of larger, established firms. (Might want to remind reader here as to why this is the case. Whether increasing managerial ownership provides a net benefit to outside shareholders of entrepreneurial firms is an unexplored empirical issue.

To examine the relationships between entrepreneurial firm value and ownership structure variables, we restrict our analysis to firms that have a book value of assets less than $\$ 45$ million, have been incorporated for 15 years or less, and have a five-year total growth rate in sales of at least $40 \%$. The resulting 108 entrepreneurial firms used in our analysis have high $Q$ values (mean $=3.81$, median $=2.31$ ). We regress Tobin's $Q$ on ownership structure variables and we control for other factors that have been highlighted in earlier studies. After controlling for the effects of firm size, research and development expenditures, financial leverage, and other factors, our linear regressions indicate that inside board member ownership is negatively related to $Q$, whereas outside board member ownership is positively related to $Q$. In tests of nonlinear relationships, we find that inside board member ownership is negatively related to $Q$ in the 5 to $25 \%$ ownership range. Inside board member ownership is not significantly related to $Q$ in the 0 to $5 \%$ range or the range above $25 \%$.

In contrast to Morck, Shleifer, and Vishny (1988), McConnell and Servaes (1990), and Mehran (1995), we find no evidence of a positive relationship between inside board member ownership and $Q$. The results from our study suggest that increasing managerial ownership imposes a net wealth loss to outside shareholders of entrepreneurial firms, but increasing outside director ownership increases the wealth of outside shareholders. A reasonable interpretation of these findings is that, for very small, young, and fast growing firms, external monitoring of top managers is a more effective means of reducing agency costs than is increasing managerial ownership.

\section{PRIOR LITERATURE AND HYPOTHESIS DEVELOPMENT}

Jensen and Meckling (1976) argue that managers' and outside shareholders' interests diverge, so outside shareholders choose some combination of managerial monitoring and managerial bonding to reduce agency costs. Managers often can be effectively monitored by outside board members or by the corporate control market. Bonding occurs when managerial wealth is tied to shareholder wealth, e.g. through managerial stock ownership or managerial 
ownership of stock options. Lippert and Moore (1995) find that managerial monitoring is a substitute, not a complement, for managerial bonding.

Not all firms have the same degree of shareholder-management conflict and the specific type of conflict can vary across firms. Large, established, slow-growing firms are more likely to have substantial free cash flow (see Jensen, 1986). These firms are more likely to experience severe principal-agent conflicts associated with managerial perquisite consumption or managerial-motivated investments in negative net present value projects (the "overinvestment problem").

Small, young, fast-growing firms are more likely to have positive net present value (NPV) investment opportunities and less likely to have free cash flow. These entrepreneurial firms are more likely to experience severe principal-agent conflict associated with managerial risk avoidance, because entrepreneurial firm managers usually have a larger proportion of their human and financial capital invested in the firm, relative to managers of large, established firms.

Smith and Smith (2000) discuss the problem of undiversified entrepreneurial managers and managerial risk avoidance. They develop a model of a young firm entrepreneur's cost of capital. Smith and Smith demonstrate that, in general, a project or firm will not be as valuable to an undiversified entrepreneur as it is to a well-diversified outside investor. Smith and Smith also show that, as the proportion of the entrepreneur's total wealth committed to the young firm increases, the entrepreneur's portfolio becomes less diversified and the entrepreneur's cost of capital increases. Thus, increasing the entrepreneur's investment in the firm can lead to the underinvestment problem. Projects that outside shareholders wish to accept will often be rejected by the entrepreneurial firm manager. We can infer from Smith and Smith's model that increasing the proportion of firm shares held by entrepreneurial firm managers increases the costs to outside shareholders associated with the underinvestment problem. Because entrepreneurial firm managers are more likely to be founders, or members of founding families, they may place a higher value on maintaining family control than on maximizing the market price of stock. This motive can lead entrepreneurial firm managers to pass up positive NPV projects that require external financing, because raising external financing increases the probability of losing family control. Also, external financing is often necessary for entrepreneurial firms because they lack sufficient internally generated cash to fund projects.

Not only does the severity and type of shareholder-management conflict vary across firms, but monitoring costs also vary across firms. For example, outside shareholders of firms in heavily regulated industries, e.g., utilities and financial services, receive "free" monitoring services from government regulators. Consistent with the suggestion that the need for managerial bonding is lower when managerial monitoring is already provided, Crawford, Ezzell, and Miles (1995) find that bank CEO pay-performance sensitivity (a measure of managerial bonding) was extremely low before the banking industry was deregulated.

Because capital markets are imperfect, and it is much easier for potential bidders to obtain the financing to acquire a small firm, outside shareholders of small firms should receive greater monitoring services from the corporate control market. As noted, Comment and Schwert (1993) conclude from a review of the finance literature and their own study that smaller firms are much more likely to become takeover targets than larger firms. Smaller firms are generally less complex and operate in fewer industries. For these reasons they should be easier for outside directors to monitor. In short, monitoring costs should be lower for small firms than for large firms.

Because entrepreneurial firm managers with low stock ownership generally receive more intense monitoring from the corporate control market and from powerful outside shareholders who sit on the firm's board of directors, the need to bond entrepreneurial firm managers through stock ownership is lessened. Furthermore, as entrepreneurial firm managers' stock ownership increases, the problems of underinvestment and managerial entrenchment are exacerbated. For these reasons, we hypothesize that entrepreneurial firm value will decrease with inside directors' stock ownership and increase with outside directors' stock ownership.

Not all research points to a significant relationship between ownership structure and firm value. Demsetz (1983) argues that ownership structure is an endogenous outcome which is influenced by many factors. He suggests 
that ownership structure can vary from firm to firm in ways that permit firm value maximization, so there should be no systematic relationship between firm performance and ownership structure. Demsetz and Lehn (1985) examine the relationship between ownership concentration and accounting performance. They find evidence that ownership structure is endogenous and they find no relationship between profitability and ownership concentration. Loderer and Martin (1997), Cho (1998), and Demsetz and Villalonga (2001) examine the relationship between firm value and ownership concentration, while treating ownership concentration as an endogenous variable. They find that ownership concentration does not have a significant influence on $Q$ in a simultaneous equations setting. However, in their measures of ownership concentration, these studies do not distinguish between inside and outside shareholders.

As mentioned, Stulz (1988) develops a model of firm value which shows a curvilinear relationship between managerial ownership and firm value. In his model, firm value initially increases as managerial ownership rises from zero. However, at higher levels of managerial ownership, an increase in ownership entrenches managers and decreases the value of the firm. Morck, Shleifer, and Vishny (1988) argue that increasing managerial ownership from zero will initially increase firm value by aligning the interests of managers and outside shareholders. They also argue that, at higher levels of managerial ownership, managers become entrenched. Therefore, increasing managerial ownership can have a negative impact on firm value in some range.

In studies that sample larger, established, slow-growing firms, Morck, et al. (1988), McConnell and Servaes (1990), and Mehran (1995) find that managerial ownership is positively related to firm value, at least over some ranges of ownership. Morck et al. (1988) also find a positive relation between outside director ownership and firm value. Hermalin and Weisbach (1988) find a positive relation between inside managerial ownership and firm performance in the 0 to $1 \%$ range.

None of these studies focuses solely on the relationship between ownership structure and firm value in small, young, fast-growing firms. Because managerial monitoring can be very effective for these firms in a low range of managerial ownership, and increasing managerial ownership can entrench managers and promote managerial risk avoidance, we predict that increasing managerial ownership will not increase entrepreneurial firm value. In contrast, we expect that entrepreneurial firm value will increase with the percentage of shares held by outside board members, because increasing outside board member ownership improves the ability of these board members to monitor and discipline managers.

\section{DATA AND METHODOLOGY}

To gather a sample of firms, we begin with the universe of companies in the 1999 Compustat active research file. We eliminate all firms in the financial services industries, the utilities industries, and firms not incorporated in the United States. Screening out these firms leaves 6,792 companies. We then impose three separate screens on these firms, based on size, growth, and age.

To focus on very small firms, we eliminate all companies with a book value of assets greater than $\$ 45$ million. Because firms with less than 500 shareholders and less than $\$ 10$ million in assets are not required to file proxy statements and annual reports with the Securities and Exchange Commission (SEC), we eliminate firms with total assets less than $\$ 10$ million. The 1,363 firms surviving after this screen represent approximately the smallest $20 \%$ of U.S. industrial firms appearing in Compustat.

To focus on fast-growing firms, we eliminate all companies that do not achieve at least a $40 \%$ increase in total sales over the most recent five year period, according to the 1999 Compustat file. If a company has only been incorporated for the most recent three to four years, or if only three to four years of data are available for the company, yet it attains a minimum $40 \%$ total growth rate in that period, we allow the firm to stay in the sample. Firms incorporated for less than three years, or that otherwise lack data for the most recent three years, were eliminated from the sample. The 273 firms surviving after this screen represent about $20 \%$ of the firms remaining after the size-based screen. 
To focus on young firms, we eliminate all companies that have been incorporated for more than 15 years. We gather the age of all remaining firms, when possible, from annual reports available on-line through the SEC. In a small number of cases this information is unavailable and those firms are eliminated from the sample. After imposing this age-based screen, the sample is reduced to 151 firms.

For each of the remaining 151 firms we attempt to gather proxy statement data and Compustat data on several variables. In many cases complete data on all variables are not available for a firm and we do not include the firm in the final sample used for the regression analysis. The final sample used for the regression analysis has 108 firms. Sample statistics for these 108 firms appear in Table 1. The mean (median) $Q$ value for the final sample of firms is 3.81 (2.31). For the 151 firms surviving the age-based screen, we attempt to calculate undistributed cash flow using Lehn and Poulsen's (1989) method. Necessary data are available for only 55 of these firms and the median value of undistributed cash flow divided by asset book value is -0.18 . (This information is not reported in Table 1.) Although the undistributed cash flow data are incomplete, these data in conjunction with the calculated $Q$ values suggest that the firms included in our final sample are very unlikely to suffer significant agency costs of free cash flow.

As in several prior studies (e.g., Morck, et al., 1988, McConnell and Servaes, 1990, and Mehran, 1995) that examine the relationship between firm value and ownership structure, we use Tobin's $Q$ as our measure of firm value. We calculate $Q$ as $(M V E+L T D+P R F) / T A$, where $M V E$ is the market value of equity, $L T D$ is the book value of longterm debt, $P R F$ is the book value of preferred stock, and $T A$ is the book value of total assets. $Q$ is regressed on ownership structure and other variables. We consider the following ownership structure variables.

\begin{tabular}{|c|c|}
\hline in_own & $\begin{array}{l}\text { insider ownership, the percentage of } \mathrm{f} \\
\text { firm }\end{array}$ \\
\hline out_own & $\begin{array}{l}\text { outsider ownership, the percentage o } \\
\text { following: officers of the firm; forme } \\
\text { known business relationships with the } \\
\text { bankers, and insurers) }\end{array}$ \\
\hline in_own5 & insider ownership less than $5 \%$ \\
\hline in_own 25 & insider ownership from $5 \%$ to $25 \%$ \\
\hline in_own $25+$ & insider ownership greater than $25 \%$ \\
\hline out_own5 & outsider ownership less than $5 \%$ \\
\hline out_own 25 & outsider ownership from $5 \%$ to $25 \%$ \\
\hline out_own $25+$ & utsider ownership greater than $25 \%$ \\
\hline
\end{tabular}

In addition to these ownership variables, we examine whether the status of the chief executive officer (CEO) as the firm's founder, or a member of the firm's founding family, is related to firm value.

founder one if the $\mathrm{CEO}$ is the founder of the firm, zero otherwise

ffamily one if the CEO is the founder or a member of the firm's founding family, zero otherwise

The evidence on founding family control and corporate performance is conflicting. In a study of Standard and Poor's 500 firms, Anderson and Reeb (2003) find that firms run by founding families are more valuable and perform better than other firms. Other evidence suggests that founding family control leads to poor firm performance, see, e.g., Morck, Strangeland, and Yeung (1998). 
Prior studies have found that the following factors are significantly related to $Q$, and we control for these influences in all regressions.

size the log of book value of assets

growth research and development expenditures divided by book value of assets

leverage long-term debt divided by book value of assets

Firm size is found to be negatively related to $Q$ by McConnell and Servaes (1990) and Mehran (1995). Growth is found to be positively related to $Q$ by Morck, et al. (1988), McConnell and Servaes (1990), and Mehran (1995). Leverage is found to be negatively related to $Q$ by Morck, et al. (1988) and positively related to $Q$ by McConnell and Servaes (1990).

In addition to these control variables, we control for the year in which the data are relevant. For most of the firms in our sample, the most recent Compustat data were relevant for 1998. However, for some firms the most recent Compustat data were relevant for 1999 (because the Compustat file we used was created in the third quarter of 1999). Also, for each of the firms in our sample, we require a proxy statement so that we can determine each board member's share ownership and the status of each board member as insider, outsider, or otherwise. For some firms in the sample, a proxy statement was not available for the most recent year that Compustat data were available. In these cases, to ensure that Compustat data and proxy statement data are time consistent, we accept proxy statements from 1996 or 1997. Thus, the Compustat data and the proxy statement data for each firm are matched in time, and each firm appears only once in our analysis, but the observation period ranges from 1996-1999. Because market-wide factors very likely influenced valuation levels during this period, we control for this effect by including indicator variables in all regressions for the years 1996, 1997, and 1998. The model intercept captures the effect for the year 1999.

\section{RESULTS}

In Table 2 we report results from regressions in which entrepreneurial firm $Q$ is regressed on the variables described earlier. In Model 1, which is specified to include only control variables, size is unrelated to firm value, growth is positively related to firm value $(\mathrm{p}=0.057)$, and leverage is negatively related to firm value $(\mathrm{p}=0.012)$. Mehran (1995) and McConnell and Servaes (1990) find that firm size is negatively related to firm value, whereas Morck, et al. (1988) find no relationship between size and firm value. To some degree, we control for firm size through our sample selection method. However, there remains size variation across sampled firms, so we include size in all of our regressions.

Our finding that growth is positively related to entrepreneurial firm value is consistent with earlier studies that sample primarily larger, well-established, slow-growing firms. Our finding that leverage is negatively related to entrepreneurial firm value is consistent with evidence in Morck, et al. (1988), but inconsistent with evidence in McConnell and Servaes (1990). Each of the year indicator variables is statistically significant, suggesting that marketwide factors have an important impact on entrepreneurial firm value.

As shown in Model 2, we find a negative, linear relationship between inside board member ownership, in_own, and entrepreneurial firm value, after controlling for the other factors mentioned. Specifically, in_own is negatively related to $Q$ at the 0.016 level of significance. Our evidence regarding insider ownership and firm value contrasts that of earlier researchers, who do not find a negative, linear relationship between these variables. For example, our evidence contrasts that of Mehran (1995), who finds a positive, linear relationship between CEO stock and option holdings and $Q$.

Although we find a negative relationship between inside board member ownership and entrepreneurial firm $Q$, in Model 3 we report that outside board member ownership, out_own, is positively related to $Q$ at the 0.022 level of significance. In Model 4 we include inside and outside board ownership, finding again that in_own is negatively related to entrepreneurial firm value $(\mathrm{p}=0.061)$, whereas out_own is positively related to entrepreneurial firm value $(\mathrm{p}$ $=0.086)$. 
Our evidence regarding outside board ownership contrasts that of Mehran (1995), who finds no relationship between outside blockholder ownership and $Q$. We also examine whether share ownership by outside blockholders is related to firm value. In results not shown in the tables, we find that outside block ownership is positively related to $Q$ $(\mathrm{p}=0.037)$. The evidence presented thus far is consistent with the assertion that increasing inside board member ownership generally creates more costs than benefits for outside shareholders of entrepreneurial firms. However, increasing the share ownership of outside directors, which increases their ability and motivation to monitor managers, seems to benefit outside shareholders of entrepreneurial firms.

As noted, prior evidence is mixed regarding the effect of founder control, and founding family control, on firm value. In Model 5 we show results when $Q$ is regressed on the indicator variable founder and the control variables. The negative coefficient on founder $(\mathrm{p}=0.073)$ suggests that outside shareholders place a lower value on entrepreneurial firms when the CEO is the firm's founder. We find similar evidence in Model 6 when founder is replaced with ffamily, an indicator variable that takes a value of one if the CEO is the founder or a member of the firm's founding family. In this case ffamily is negatively related to $Q$ at the 0.088 level of significance.

This evidence above is consistent with founders or founding families extracting private benefits at outside shareholders' expense. However, regression results using Model 7 show that the variable founder loses significance when accompanied by in_own and out_own. In results not shown, ffamily also loses significance when accompanied by in_own and out_own. Given the positive correlation between founder control and inside board ownership, this perhaps is not surprising. Still, our evidence regarding the effect of founder and founding family control on entrepreneurial firm value should be interpreted with caution.

Morck, et al. (1988) argue that, at lower levels of managerial ownership, increasing managerial ownership increases firm value by aligning managers' interests more closely with those of outside shareholders. But at higher levels of managerial ownership, increasing managerial ownership decreases firm value by entrenching managers. Consistent with their argument, they find that share ownership by the two top firm officers is positively related to $Q$ in the 0 to $5 \%$ ownership range, negatively related to $Q$ in the 5 to $25 \%$ range, and positively related to $Q$ in the range above $25 \%$. For the remaining board members (which are presumed to be dominated by outsiders) they find that share ownership is positively related to $Q$ in the 0 to $5 \%$ range, negatively related to $Q$ in the 5 to $25 \%$ range, and unrelated to $Q$ in the range above $25 \%$.

In view of the evidence presented by Morck, et al. (1988), we search for a curvilinear relationship between inside board member ownership, outside board member ownership, and firm value. The results of these tests appear in Table 3. In Model 1 we show the regression results using all control variables, in_own5, in_own25, and in_own $25+$. The coefficient estimate on in_own 25 is negative and significant at the 0.018 level. The coefficient estimates for in_own5 and in_own 25+ are not significant. Although we do find evidence suggesting that the agency costs of managerial entrenchment are important in the 5 to $25 \%$ range, in no range of ownership do we find evidence that increasing managerial ownership increases entrepreneurial firm value by aligning the interests of managers and outside shareholders.

The results using Model 2, which includes out_own5, out_own25, and out_own25+, suggests that there is no curvilinear relationship between outside board ownership and entrepreneurial firm value. When outside board ownership is broken up into the three ranges, none of these variables is found to have significant explanatory power. Model 3 shows results when in_own5, in_own25, in_own $25+$, out_own5, out_own25, and out_own25+ are all included in the model specification. Again, no curvilinear relationship is found for outside board member ownership, but inside board member ownership is negatively related to firm value in the 5 to $25 \%$ range $(p=0.051)$.

To check the robustness of our results, we replace the book value of assets with total sales as our firm size variable and we redefine the control variables growth and leverage so that they are scaled by total sales rather than by total assets. We then estimate again all of the models appearing in Tables 2 and 3. The results of these regressions support our main conclusions regarding inside board ownership and outside board ownership. As before, the variables in_own and in_own 25 are significantly, negatively related to $Q$. In no case do we find evidence that inside board ownership increases firm value. The variable out_own is significantly, positively related to $Q$. 
Finally, Pi and Timme (1993) find evidence that agency conflicts between managers and shareholders increase when the CEO also serves as the board chair. Other writers suggest that, as the percentage of board members who are outsiders increases, agency conflicts between managers and shareholders are reduced. We test whether the status of the CEO as board chair or the composition of the board (as opposed to share ownership by the board) is related to entrepreneurial firm value. In regressions that include the same control variables used throughout this study, neither of these two corporate governance variables is found to have significant explanatory power.

\section{CONCLUSION}

In this study we investigate the relationship between ownership structure and the market value of firms for a sample of very small, young, and fast-growing firms. The techniques that we use are similar to those employed by Morck, Shleifer, and Vishny (1988), and in more recent studies that examine how the concentration of share ownership influences firm value. Morck, et al. (1988) argue that, when managerial ownership is low, increasing managerial ownership increases firm value by aligning the interests of managers and shareholders. However, when managerial ownership is high, increasing managerial ownership decreases firm value by entrenching managers. Using a sample of large, established firms, Morck, et al. (1988) find evidence that supports their argument.

Our study differs from Morck, et al. (1988) and related studies primarily in sample selection. Because we select very small, young, and fast-growing businesses, which we call "entrepreneurial firms," the firms in our sample are more likely than others to have profitable investment opportunities and less likely to have free cash flow. When managerial ownership is low, top managers of entrepreneurial firms are more likely than other managers to face intense external monitoring from outside board members and from the corporate control market.

Because entrepreneurial firm managers face effective external monitoring and have little opportunity to waste free cash flow, we argue that increasing managerial ownership generally will not serve to decrease the agency costs of principal-agent conflict, even in a low range of managerial ownership. In entrepreneurial firms, the principal-agent conflicts most likely to arise are those associated with managerial risk avoidance (because managers are undiversified) and managerial entrenchment. Both of these agency problems are exacerbated as managerial share ownership increases.

Using a sample of 108 very small firms that are incorporated for 15 years or less, and that experienced a rapid sales growth, we find no evidence that increasing inside board ownership increases firm value. Instead, we find that inside board ownership is negatively related to entrepreneurial firm value (Tobin's $Q$ ) in linear regressions. In tests of a nonlinear influence, we find that inside board ownership in the 5 to $25 \%$ range is negatively related to firm value. The other ranges of inside board ownership are unrelated to firm value. We provide additional evidence that outside board ownership is positively related to firm value. Weaker evidence suggests that firm value is lower when founders or members of the founding family hold the CEO position.

The evidence from this study contrasts that of Morck, et al. (1988), McConnell and Servaes (1990), Mehran (1995) and other studies that emphasize relatively larger, more established firms. Larger, more established firms are more likely than other firms to suffer the agency cost of free cash flow discussed by Jensen (1986). Morck, et al. (1988), McConnell and Servaes (1990), and Mehran (1995) find a positive relationship between managerial ownership and firm value, at least in a low range of ownership. We conclude from their evidence and ours that increasing managerial ownership is more likely to benefit outside shareholders when the agency cost of free cash flow is the principal-agent conflict of greatest concern. However, increasing managerial ownership is less likely to benefit outside shareholders when the principal-agent conflicts of greatest concern are managerial entrenchment and managerial risk avoidance.

\section{NOTES}

1. The authors acknowledge the helpful comments of (name omitted from blind referee).

2. See, e.g., Berle and Means, 1932, Jensen and Meckling, 1976, Leland and Pyle, 1977, Amihud and Lev, 1981, Fama and Jensen, 1983a, Demsetz and Lehn, 1985, and Stulz, 1988. 
3. On page 314 they state that “... we have focused on very large (and therefore usually older) corporations. In newer, faster growing firms, managerial holdings probably play a more important signaling or compensation role than they do in our firms. . Research on ownership structure can doubtless[ly] benefit from considering small firms as well."

4. Smith and Smith (2000) point out that managers of new ventures (entrepreneurs) often have less established records of achievement. This hinders the ability of new venture managers to gain financing and raises the cost of failure to the managers. If the new venture fails, these top managers may have a particularly difficult time finding satisfying employment.

5. $\quad$ See pages 314-358.

6. For evidence that founding family members pursue goals other than outside shareholder wealth maximization, see Morck, Strangeland, and Yeung (1998).

7. This argument is less important for our study, because we sample firms with similar attributes.

8. The $40 \%$ growth rate restriction is based on the firm's total growth rate over the years, not an annual growth rate. Assuming a firm achieves the exact minimum $40 \%$ growth rate in five years, the compounded annual growth rate in sales over the five year period would be about $7 \%$.

9. A minority of board members are considered "grey" directors, because they do not fit the definitions of insider or outsider. Grey members have the potential for conflicts of interests with shareholders (similar to insiders), but they also have the potential to act as managerial monitors for shareholders (similar to outsiders). Our evidence, not shown in the tables, suggests that ownership by grey board members is unrelated to firm value.

10. The negative relation we observe between firm value and leverage is also consistent with Myers (1977), who argues that debt decreases value in firms that have significant growth opportunities.

11. We also replace in_own with the percentage of firm shares held solely by the CEO. The results (not shown) suggest that CEO ownership is negatively, linearly related to entrepreneurial firm value $(\mathrm{p}=0.092)$.

12. We define outside blockholder ownership as the percentage of shares owned by all outside shareholders who each own $5 \%$ or more of the firm's shares.

\section{REFERENCES}

1. Amihud, Y. and B. Lev (1981), Risk reduction as a managerial motive for conglomerate mergers, Bell Journal of Economics, Vol. 12, pp. 605-617.

2. Anderson, R.C. and D. M. Reeb (2003), Founding-family ownership and firm performance: evidence from the S\&P 500, Journal of Finance forthcoming.

3. Berle, A.A. Jr. and G.C. Means (1932), The modern corporation and private property, (Macmillan, New York).

4. Cho, M.-H. (1998), Ownership structure, investment, and the corporate value: an empirical analysis, Journal of Financial Economics, Vol. 47, pp. 103-121.

5. Comment, R. and G.W. Schwert (1993), Poison or placebo?: evidence on the deterrent and wealth effects of modern antitakeover measures, Journal of Financial Economics, Vol. 39, pp. 3-44.

6. Crawford, A., J. Ezzell, and J. Miles (1995), 'Bank CEO pay-performance relations and the effects of deregulation', Journal of Business, Vol. 68, pp. 231-256.

7. Demsetz, H. (1983), The structure of ownership and the theory of the firm, Journal of Law and Economics, Vol. 26, pp. 375-390.

8. Demsetz, H. and K. Lehn (1985), The structure of corporate ownership: causes and consequences, Journal of Political Economy, Vol. 93, pp. 1155-1177.

9. Demsetz, H. and B. Villalonga (2001), Ownership structure and corporate performance, Journal of Corporate Finance, Vol. 7, pp. 209-233.

10. Fama, E.F. and M. Jensen (1983a), Separation of ownership and control, Journal of Law and Economics, Vol. 26, pp. 301-326.

11. Hermalin, B. and M. Weisbach (1988), The determinants of board composition, RAND Journal of Economics, Vol. 19, pp. 589-606.

12. Jensen, M.C. (1986), Agency costs of free cash flow, corporate finance, and takeovers, American Economic Review, Vol. 76, pp. 323-329. 
13. Jensen, M.C. and W.H. Meckling (1976), Theory of the firm: Managerial behavior, agency costs and ownership structure, Journal of Financial Economics, Vol. 3, pp. 305-360.

14. Lehn, K. and Poulsen, A. (1989), Free cash flow and stockholder gains in going private transactions, Journal of Finance, Vol. 44, pp. 771-788.

15. Leland, M. and D. Pyle (1977), Informational asymmetries, financial structure, and financial intermediation, Journal of Finance, Vol. 32, pp. 371-387.

16. Lippert R. and W. Moore (1995), Monitoring versus bonding: shareholder rights and management compensation, Financial Management, Vol. 24, pp. 54-62.

17. Loderer, C. and K. Martin (1997), Executive stock ownership and performance: tracking faint traces, Journal of Financial Economics, Vol. 45, pp. 223-255.

18. McConnell, J.J. and H. Servaes (1990), Additional evidence on equity ownership and corporate value, Journal of Financial Economics, Vol. 27, pp. 595-612.

19. Mehran, H. (1995), Executive compensation structure, ownership, and firm performance, Journal of Financial Economics, Vol. 38, pp. 163-184.

20. Morck, R., A. Shleifer, and R.W. Vishny (1988), Management ownership and market valuation: an empirical analysis, Journal of Financial Economics, Vol. 20, pp. 293-315.

21. Morck, R.K., D.A. Strangeland, and B. Yeung (1998), Inherited wealth, corporate control, and economic growth: the Canadian disease, NBER Working Paper No. 6814.

22. Myers, S. C. (1977), Determinants of corporate borrowing, Journal of Financial Economics, Vol. 5, pp. 147175.

23. Pi, L. and S.G. Timme (1993), Corporate control and bank efficiency, Journal of Banking and Finance, Vol. 20, pp. 515-530.

24. Smith, R.L. and J.K. Smith (2000), Entrepreneurial Finance, (John Wiley and Sons, New York).

25. Stulz, R.M. (1988), Managerial control of voting rights: financing policies and the market for corporate control, Journal of Financial Economics, Vol. 20, pp. 25-54.

\section{Table 1: Descriptive Data for Entrepreneurial Firms}

Shown are summary statistics for 108 entrepreneurial firms that survived three sample selection criteria. Each firm had \$10-45million in total assets according to the most recent data on the 1999 Compustat file, was incorporated for 15 years or less at the end of 1998, and achieved at least a $40 \%$ total sales growth rate in the most recent 5 years (or less), according to the 1999 Compustat file. To match proxy data in time with Compustat data, we use data that are current in 1996-1999. Tobin's $Q$ is calculated as $(M V E+L T D+P R F) / T A$, where $M V E$ is the market value of equity, $L T D$ is the book value of long-term debt, $P R F$ is the book value of preferred stock, and $T A$ is the book value of assets. Growth is calculated as research and development expenditures divided by book value of assets. Leverage is calculated as long-term debt divided by book value of assets. Inside board ownership and outside board ownership are the percentages of total firm shares held by inside and outside board members, respectively. Undistributed cash flow is a proxy for free cash flow, calculated according to Lehn and Poulsen's (1989) method. Compustat data are incomplete for this variable, so the sample size used to calculate undistributed cash flow is only 55 firms.

\begin{tabular}{|c|c|c|c|c|c|c|}
\hline Variable & $\mathbf{n}$ & Mean & Median & $\begin{array}{c}\text { Standard } \\
\text { Deviation }\end{array}$ & Max. & Min. \\
\hline Tobin's Q & 108 & 3.806 & 2.309 & 4.041 & 22.277 & 0.200 \\
\hline Ln (Total Assets) (\$mill.) & 108 & 3.215 & 3.290 & 0.620 & 5.386 & 0.378 \\
\hline Growth (R\&D/Assets) & 108 & 0.228 & 0.128 & 0.286 & 1.268 & 0.00 \\
\hline Leverage (LTD/Assets) & 108 & 0.095 & 0.024 & 0.140 & 0.565 & 0.00 \\
\hline Inside board ownership & 108 & 0.146 & 0.097 & 0.154 & 0.710 & 0.00 \\
\hline Outside board ownership & 108 & 0.084 & 0.023 & 0.131 & 0.716 & 0.00 \\
\hline Undistributed Cash Flow & 55 & -0.345 & -0.181 & 0.511 & 0.292 & -2.145 \\
\hline
\end{tabular}


Table 2: Linear Relationships between Firm Value and Ownership Structure

Shown are the results of regressing firm value on ownership structure and other variables. The dependent variable is Tobin's $Q$. Tobin's $Q$ is calculated as $(M V E+L T D+P R F) / T A$, where $M V E$ is the market value of equity, $L T D$ is the book value of long-term debt, $P R F$ is the book value of preferred stock, and $T A$ is the book value of assets. Size is the log of total asset book value. Growth is calculated as research and development expenditures divided by book value of assets. Leverage is calculated as long-term debt divided by book value of assets. Each firm's data is collected for 1996, 1997, 1998, or 1999, whichever is most current and complete. The variables 1996, 1997, and 1998 are indicator variables which take a value of one if the firm's data were current in 1996, 1997, or 1998, respectively. The intercept captures the effect for 1999. The variables in_own and out_own are the percentages of total firm shares held by inside and outside board members, respectively. The variable founder is an indicator variable set to one if the CEO is the firm's founder. The variable ffamily is an indicator variable set to one if the $\mathrm{CEO}$ is the founder or a member of the founding family. P-values are shown in parentheses. The number of observations is 108 firms.

\begin{tabular}{|l|l|l|l|l|l|l|l|}
\hline & $(1)$ & $(2)$ & $(3)$ & $(4)$ & $(5)$ & $(6)$ & $(7)$ \\
\hline intercept & 7.911 & 9.77 & 7.653 & 9.198 & 8.839 & 8.864 & 9.325 \\
& $(0.004)$ & $(0.000)$ & $(0.004)$ & $(0.001)$ & $(0.001)$ & $(0.001)$ & $(0.001)$ \\
\hline size & -0.247 & -0.408 & -0.309 & -0.423 & -0.316 & -0.334 & -0.428 \\
& $(0.716)$ & $(0.541)$ & $(0.643)$ & $(0.522)$ & $(0.639)$ & $(0.621)$ & $(0.519)$ \\
\hline growth & 2.400 & 1.176 & 2.298 & 1.346 & 1.961 & 1.995 & 1.338 \\
& $(0.057)$ & $(0.373)$ & $(0.062)$ & $(0.305)$ & $(0.121)$ & $(0.115)$ & $(0.309)$ \\
\hline leverage & -6.599 & -6.808 & -7.394 & -7.375 & -7.089 & -7.040 & -7.529 \\
& $(0.012)$ & $(0.008)$ & $(0.004)$ & $(0.004)$ & $(0.007)$ & $(0.007)$ & $(0.004)$ \\
\hline 1996 & 5.422 & 6.003 & 5.199 & 5.714 & 5.456 & 5.418 & 5.652 \\
& $(0.050)$ & $(0.027)$ & $(0.055)$ & $(0.034)$ & $(0.046)$ & $(0.048)$ & $(0.036)$ \\
\hline 1997 & -3.583 & -3.663 & -3.366 & -3.479 & -3.590 & -3.592 & -3.476 \\
& $(0.004)$ & $(0.002)$ & $(0.006)$ & $(0.004)$ & $(0.003)$ & $(0.003)$ & $(0.004)$ \\
\hline 1998 & -4.045 & -4.347 & -4.056 & -4.295 & -4.171 & -4.190 & -4.304 \\
& $(0.000)$ & $(0.000)$ & $(0.000)$ & $(0.000)$ & $(0.000)$ & $(0.000)$ & $(0.000)$ \\
\hline in_own & & -5.941 & & -4.734 & & & -3.919 \\
& & $(0.016)$ & & $(0.061)$ & & & $(0.164)$ \\
\hline out_own & & & 5.976 & 4.585 & & & 4.456 \\
& & & $(0.022)$ & $(0.086)$ & & & $(0.097)$ \\
\hline founder & & & & & $(0.073)$ & & -0.522 \\
& & & & & & $(0.508)$ \\
\hline ffamily & & & & & & $0.088)$ & \\
\hline Adj. R ${ }^{2}$ & 0.251 & 0.286 & 0.282 & 0.300 & 0.268 & 0.265 & 0.296 \\
\hline
\end{tabular}




\section{Table 3: Nonlinear Relationships between Firm Value and Ownership Structure}

Shown are the results of regressing firm value on ownership structure and other variables. The dependent variable is Tobin's $Q$. Tobin's $Q$ is calculated as $(M V E+L T D+P R F) / T A$, where $M V E$ is the market value of equity, $L T D$ is the book value of long-term debt, $P R F$ is the book value of preferred stock, and $T A$ is the book value of assets. Size is the log of total asset book value. Growth is calculated as research and development expenditures divided by book value of assets. Leverage is calculated as long-term debt divided by book value of assets. Each firm's data is collected for 1996, 1997, 1998, or 1999, whichever is most current and complete. The variables 1996, 1997, and 1998 are indicator variables which take a value of one if the firm's data were current in 1996, 1997, or 1998, respectively. The intercept captures the effect for 1999. The variables in_own5, in_own25, and in_own25+ are the percentage of shares held by board insiders, when that percentage ranges from $0 \%$ to $5 \%$, greater than $5 \%$ to $25 \%$, and above $25 \%$, respectively. The variables out_own 5 , out_own 25 , and out_own $25+$ are the percentage of shares held by board outsiders, when that percentage ranges from $0 \%$ to $5 \%$, greater than $5 \%$ to $25 \%$, and above $25 \%$, respectively. P-values are shown in parentheses. The number of observations is 108 firms.

\begin{tabular}{|c|c|c|c|}
\hline & (1) & (2) & (3) \\
\hline Intercept & $\begin{array}{c}9.092 \\
(0.002)\end{array}$ & $\begin{array}{c}7.819 \\
(0.005)\end{array}$ & $\begin{array}{c}8.929 \\
(0.004)\end{array}$ \\
\hline size & $\begin{array}{c}-0.493 \\
(0.463)\end{array}$ & $\begin{array}{c}-0.328 \\
(0.628)\end{array}$ & $\begin{array}{c}-0.523 \\
(0.442)\end{array}$ \\
\hline growth & $\begin{array}{c}0.793 \\
(0.569)\end{array}$ & $\begin{array}{c}2.163 \\
(0.086)\end{array}$ & $\begin{array}{c}0.847 \\
(0.550)\end{array}$ \\
\hline leverage & $\begin{array}{c}-6.622 \\
(0.011)\end{array}$ & $\begin{array}{c}-7.277 \\
(0.006)\end{array}$ & $\begin{array}{l}-7.000 \\
(0.008)\end{array}$ \\
\hline 1996 & $\begin{array}{c}5.946 \\
(0.028)\end{array}$ & $\begin{array}{c}4.941 \\
(0.075)\end{array}$ & $\begin{array}{c}5.395 \\
(0.050)\end{array}$ \\
\hline 1997 & $\begin{array}{c}-3.557 \\
(0.003)\end{array}$ & $\begin{array}{c}-3.310 \\
(0.007)\end{array}$ & $\begin{array}{l}-3.363 \\
(0.006)\end{array}$ \\
\hline 1998 & $\begin{array}{l}-4.465 \\
(0.000)\end{array}$ & $\begin{array}{c}-4.109 \\
(0.000)\end{array}$ & $\begin{array}{l}-4.464 \\
(0.000)\end{array}$ \\
\hline in_own5 & $\begin{array}{l}35.241 \\
(0.219)\end{array}$ & & $\begin{array}{l}31.188 \\
(0.285)\end{array}$ \\
\hline in_own25 & $\begin{array}{c}-16.197 \\
(0.018)\end{array}$ & & $\begin{array}{c}-13.862 \\
(0.051)\end{array}$ \\
\hline in_own25+ & $\begin{array}{c}-1.363 \\
(0.773)\end{array}$ & & $\begin{array}{l}-0.961 \\
(0.840)\end{array}$ \\
\hline out_own5 & & $\begin{array}{l}-1.767 \\
(0.938)\end{array}$ & $\begin{array}{c}-6.494 \\
(0.774)\end{array}$ \\
\hline out_own25 & & $\begin{array}{c}10.601 \\
(0.149)\end{array}$ & $\begin{array}{c}9.136 \\
(0.209)\end{array}$ \\
\hline out_own25+ & & $\begin{array}{c}1.667 \\
(0.814)\end{array}$ & $\begin{array}{l}-0.611 \\
(0.931)\end{array}$ \\
\hline Adj. $R^{2}$ & 0.293 & 0.271 & 0.291 \\
\hline
\end{tabular}

